\title{
PENYUSUNAN INSTRUMEN EVALUASI PEMBELAJARAN BERBASIS THINKING ANALYSIS DALAM UPAYA PENINGKATAN KOMPETENSI GURU MATEMATIKA
}

\author{
Asri Bekti Pratiwi, Yayuk Wahyuni, Herry Suprajitno \\ Departemen Matematika Fakultas Sains dan Teknologi, Universitas Airlangga \\ e-mail: asri.bekti@fst.unair.ac.id,yayuk-w@fst.unair.ac.id, herry-s@fst.unair.ac.id
}

\begin{abstract}
ABSTRAK
Menyiapkan tenaga kerja yang mampu berpikir analitis menjadi salah satu tugas institusi pendidikan, baik perguruan tinggi maupun sekolab menengah atas. Kegiatan pengabdian kepada masyarakat bertujuan ini untuk meningkatkan kompetensi guru Matematika SMA dalam menyusun instrumen evaluasi pembelajaran berbasis Thinking Analysis, yaitu penyusunan soal kategori Higher Order Thinking Skills (HOTS).Kegiatan ini bekerjasama dengan mitra yaitu MGMP Matematika SMA/MA se-Kabupaten Tuban. Rangkaian kegiatan dimulai dengan penugasan awal untuk peserta berupa penyusunan soal HOTS. Kegiatan berikutnya yang merupakan kegiatan utama kegiatan pengabdian masyarakat ini adalah pelatiban penyusunan soal kategori HOTS dan penelaahan selurub soal HOTS yang telah dikumpulkan oleh peserta yang diikuti oleh 30 peserta guru Matematika SMA di Kabupaten Tuban didampingi oleh tim instruktur. Selanjutnya kegiatan telaah soal oleh tim reviewer terhadap soal yang telah disusun oleh setiap peserta. Rangkaian kegiatan ini ditutup dengan evaluasi atas keseluruban pelaksanaan kegiatan serta hasil penyusunan soal. Berdasarkan hasil evaluasi secara keseluruban tampak bahwa kompetensi peserta dalam penyusunan soal HOTS mengalami peningkatan jika dibandingkan dengan sebelum mendapatkan pelatiban. Disamping itu, peserta lebih percaya diri dalam menyusun soal kategori HOTS. Luaran kegiatan ini salah satunya berupa e-book yang merupakan kumpulan seluruh soal yang telah disusun oleh peserta sebagai referensi bagi guru SMA Matematika se-Kabupaten Tuban guna penyusunan soal selanjutnya.
\end{abstract}

Kata kunci: HOTS, Kompetensi, Instrumen evaluasi pembelajaran, Matematika

\begin{abstract}
Preparing a workforce capable of analytical thinking is one of the tasks of educational institutions, both tertiary institutions and high schools. This community service activity aims to improve the competence of SMA Mathematics teachers in developing Thinking Analysis-based learning evaluation instruments, namely the creation of Higher Order Thinking Skills (HOTS) category questions. This activity was in collaboration with a partner, namely the Mathematics MGMP of $S M A / M A$ in the Tuban area. This series of activities began with an initial assignment for participants in the form of creating HOTS questions. The main activity of this community service activity was the HOTS category question creation training, which was attended by 30 participants, mathematics senior high school teachers from the Tuban area, and continued with HOTS activities by participants accompanied by a team of instructors. Next was the question review activity by the
\end{abstract}


reviewer team against the questions that had been compiled by each participant. This series of activities concluded with an assessment of the overall implementation of the activities as well as the results of the question preparation.Based on the results of the overall evaluation, it appears that the competence of participants in preparing HOTS questions has increased when compared to before receiving training. Besides that, the participants also became confident in compiling the HOTS category questions. One of the outcomes of this activity is an e-book, which is a compilation of all the questions compiled by the participants and will be used as a reference for SMA Mathematics teachers in the Tuban area in the preparation of future questions.

Keywords: HOTS, Competence, Learning evaluation instrument, Mathematics

\section{PENDAHULUAN}

Dunia digital seperti sekarang ini ditandai dengan perubahan yang terjadi begitu cepatsehingga menimbulkan banyak permasalahan sekaligus tantangan. Dalam dunia kerjapun juga demikian, berbagai permasalahan terjadi dan harus segera dicari penyelesaiannya. Untuk itu diperlukan orang yang mampu berpikir cepat dalam menyelesaikan permasalahan tersebut, salah satunya melalui kemampuan berpikir analitis. Berpikir analitis merupakan salah satu aspek kognitif untuk bekerja secara sistematis, dimana seseorang dapat menguraikan atau memisahkan suatu hal berdasarkan bagian-bagiannya sehingga mampu menemukan keterkaitan dari bagianbagian tersebut. Seseorang yang memiliki pola pikir analitis biasanya mampu melihat suatu permasalahan secara menyeluruh sehingga dapat menemukan letak kesalahan dan segera menemukan jalan keluarnya.

Menurut Bloom, seorang ahli psikologi pendidikan, pola pikiranalitis menekankan pada pemecahan materi kedalam bagian yang lebih khusus dan mendeteksi hubungan antara bagian-bagian tersebut serta menyatukannya menjadi suatusolusi atau pemecahan dari permasalahan tersebut.Menyiapkan tenaga kerja yang mampu berpikir analitis menjadi salah satu tugasinstitusi pendidikan, baik perguruan tinggi maupun sekolah menengah atas.Institusipendidikan tinggi menyiapkan tenaga kerja berkualitas melalui serangkaian pembelajaranyang mengasah mahasiswa untuk berpikir analitis, kritis, dan inovatif.

Program Studi Matematika Fakultas Sains dan Teknologi sebagai salah satu program studi yang ada di Universitas Airlangga juga menjalankan visi seperti di atas. Dari hasil pembelajaran Kalkulus untuk mahasiswa tingkat dasar di Fakultas Sains dan Teknologi dapat diperoleh gambaran bagaimana kemampuan analitis lulusan 


\section{Indonesian Engagement Journal}

Vol. 2 No. 1 Juni 2021

SMA setelah perkuliahan tahun pertama pada beberapa program studi di Fakultas Sains Teknologi dan Fakultas Farmasi. Hasil pembelajaran Kalkulus dua tahun terakhir menunjukkan rata-rata kemampuan mahasiswapeserta mata kuliah tersebut dalam penyerapan materi perkuliahan, berturut-turut sebesar 54,75\% dan 51,8\%. Hasil ini menunjukkan bahwa pembelajaran yang mengasah peserta didik untuk mampu berpikir analitis masih perlu terus ditingkatkan.

Salah satu cara meningkatkan kemampuan berpikir analitis adalah menggunakan pendekatan aktif melalui pengerjaan soal matematika. ${ }^{1}$ Pembelajaran matematika di tingkat Sekolah Menengah Atas baik umum maupun kejuruan selain ditujukan untuk mencapai kemampuan matematis yang ditetapkan juga untuk mengasah kemampuan berpikir analitis. Hasil UN tingkat Sekolah Menengah Atas menunjukkan penggunaan soal tipe HOTS (mulai tahun 2017) menurunkan rerata nilai UN matematika secara signifikan. ${ }^{2}$ Ini semakin memperkuat dugaan bahwa soal tipe HOTS masih menjadi kesulitan tersendiri bagi siswa peserta ujian. Rerata nilai UN bidang Matematika selama 5 tahun terakhir disajikan pada gambar berikut:

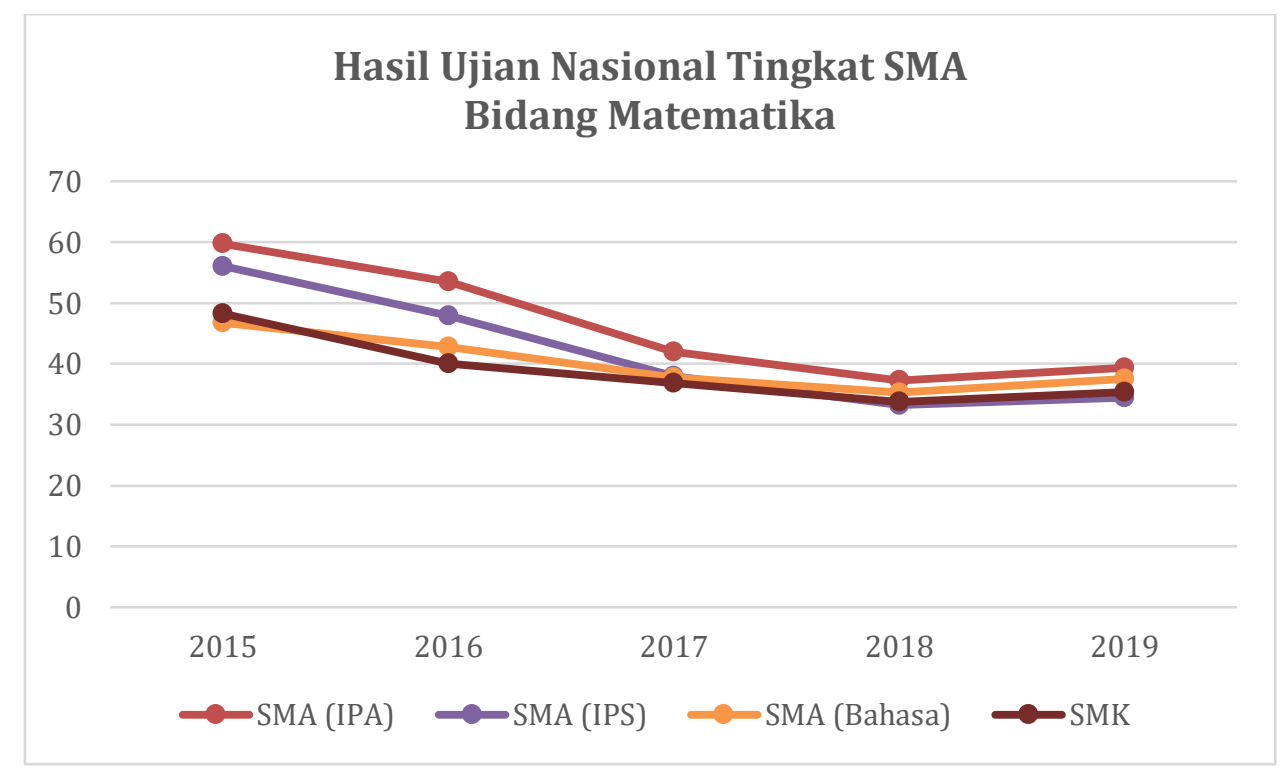

Gambar 1. Hasil Ujian Nasional Tingkat SMA Bidang Matematika

\footnotetext{
1 Wikihow (2020), "Cara MeningkatkanKetrampilan Analitis," https://id.wikihow.com/Meningkatkan-Keterampilan-Analitis, akses 23 Maret 2020.

2 Pusat Penilaian Pendidikan Kementerian Pendidikan dan Kebudayaan (2020), https://hasilun.puspendik.kemdikbud.go.id/, akses 23 Maret 2020
} 
Sesuai dengan kepanjangannya, soal HOTS adalah soal yang membutuhkanketerampilan berpikir tingkat tinggi untuk menyelesaikannya. Biasanya informasi yangterkandung dalam soal harus dianalisis terlebih dahulu, baru kemudian dipilih metode untuk menyelesaikan soal tersebut. Bagi siswa dan guru yang belum terbiasa menyelesaikan soal HOTS, tentu akan menemui kesulitan dalam menggali informasi yang terkadang tidak tampak secara jelas/langsung. Oleh karena itu, keterampilan mengidentifikasi berbagai informasi yang tersurat maupun tersirat dalam suatu soal beserta implikasinya merupakan kemampuan yang harus diasah secara terus-menerus.

Hasil survei awal (need assessment) yang dilakukan oleh tim pengabdiankepada masyarakatProgram Studi Matematika Fakultas Sains dan Teknologi Universitas Airlangga terhadapguru Matematika SMA di Kabupaten Tuban dengan responden sebanyak 41 orangmenunjukkan bahwafrekuensi penggunaan soal HOTS dalam pembelajaran, baik dalam latihan maupun ujianmasih kurang (80,5\% menyatakan jarang menggunakan bahkan 17,1\% tidak pernahmenggunakan). Padahal kebutuhan soal secara umum masih sangat banyak $(65,9 \%$ responden membutuhkan soal untuk latihan; 97,6\% untuk ulangan harian;78\% untukpenilaian tengah semester; dan 82,9\% untuk penilaian akhir semester). Sementara ituaktivitas guru untuk membuat soal dalam satu semester juga cukup banyak (58,5\% membuat soal lebih dari 4 kali; 34,1\% membuat sebanyak 3-4 kali). Kebijakan Dinas Pendidikan di Tuban yang memberikan keleluasaan kepada guru untuk menyusun soal evaluasi yang digunakan di masing-masing sekolah membuat kebutuhan akan kemampuan menyusun soal khususnya tipe HOTS menjadi sebuah keniscayaan. Oleh karena itu peningkatan kemampuan guru (khususnya guru Matematika SMA) untuk dapat menyusun soal HOTS sangat mendesak untuk dilakukan, dalam bentuk pelatihan dan pendampingan

Berdasarkan permasalahan tersebut, tim pelaksana pengabdiankepada masyarakat bekerja sama dengan Musyawarah Guru Mata Pelajaran (MGMP) SMA Matematika se-Kabupaten Tuban telah melaksanakan kegiatan Pelatihan Penyusunan Instrumen Evaluasi Pembelajaran Berbasis Thinking Analysis dalam Upaya Peningkatan Kompetensi Guru Matematika se-wilayah Kabupaten Tuban. Bagian selanjutnya menjelaskan mengenai Metode Pelaksanaan Pengabdian kepada 
Masyarakat. Analisis serta Pembahasan dari hasil kegiatan Pengabdian kepada Masyarakat disajikan pada Bagian selanjutnya dan Kesimpulan sebagai penutup.

\section{METODE}

Kegiatan pengabdian kepada masyarakatterdiri dari serangkaian kegiatan yang terdiri dari dua tahapan yaitu tahap pertama merupakan kegiatan pelatihan serta tahap kedua merupakan kegiatan evaluasi yang dilaksanakan masing-masing selama satu hari. Kegiatan pelatihan diberikan dalam bentuk ceramah dan diskusi, pendampingan dan pembahasan soal HOTS, serta pemberiantugas. Sebelum diselenggarakan kegiatan Pelatihan, peserta terlebih dahulu mendapatkan pra-pelatihan yaitu berupa penugasan penyusunan soal yang selanjutnya soal tersebut dibahas pada sesi pendampingan di kelas paralel. Pada akhir kegiatan pelatihan, peserta diberi tugas menyusun soal HOTS. Soal yang telah dikirim kepada tim pelaksanaselanjutnyaditelaah. Hasil telaahyang telah diverifikasi terbagi dalamdua kelompok, yaitu diterima (artinya soal tersebut memenuhi kategori HOTS) atau tidakditerima. Soal yang status telaahnya tidak diterimaselanjutnya dikembalikan kepada peserta untuk diperbaiki.Tahap kedua sekaligus bagian akhir dari kegiatan pengabdian kepada masyarakat ini berupa kegiatan evaluasi, yaitu evaluasi kegiatan pelatihan serta evaluasi penyusunan soal oleh peserta.

Kegiatan pengabdian kepada masyarakat ini dilaksanakan secara kemitraan anatara tim pelaksana yang terdiri dari dosen Departemen Matematika Fakultas Sains dan Teknologi Universitas Airlangga dengan guru Matematika SMA yang tergabung dalam MGMP Matematika SMA se-Kabupaten Tuban. Kegiatan pelatihan diselenggarakan di SMA Negeri 3 Tuban.

\section{ANALISIS DAN PEMBAHASAN}

Secara garis besar kegiatan pengabdian kepada masyarakat ini dibagi menjadi empat sub kegiatan yaitu: pelatihan, telaah soal, evaluasi pelatihan dan penyusunan soal, serta luaran kegiatan. Masing-masing sub kegiatan diuraikan sebagai berikut.

\section{Pelatihan}

Kegiatan pelatihan penyusunan instrumen evaluasi pembelajaran kategori Higher Order Thinking Skills (HOTS) dilaksanakan selama satu hari pada tanggal 17 
Oktober 2020 di SMA Negeri 3 Tuban. Penugasan awal peserta pelatihan berupa penyusunan soal diberikan seminggu sebelum kegiatan pelatihan tersebut. Pelatihan diikuti oleh guru Matematika SMA se-wilayah Kabupaten Tuban sebanyak 30 orang denganaktivitas dapat dijelaskan sebagai berikut:

1. Pemberian materi tentang "Pengertian HigherOrder Thinking Skills (HOTS)" dilanjutkan materi tentang "Pengembangan Soal HOTS", dan terakhir materi tentang "Kaidah Penyusunan Soal". Materi disampaikan dengan metode ceramah dan diskusi disertai pemberian contoh soal yang ditulis sesuai kaidah dan dalam kategori HOTS maupun bukan HOTS.

2. Pendampingan penyusunan soal kategori HOTS serta pembahasan terhadap soal yang telah dikirimkan oleh peserta. Peserta dikelompokkan ke dalam tiga kelas paralel yaitu kelas X, XI, atau XII sesuai dengan kelas yang peserta ampu di sekolah masing-masing. Kegiatan pendampingan serta analisis soal ini dilakukan bersama-sama antara peserta dantim instruktur. Hasil dari kegiatan analisa soal tersebut, peserta mengetahui kekurangan soal yang telah disusunserta mendapat masukan dari tim instruktur mengenai soal yang dapat dimodifikasi agar menjadi soal kategori HOTS. Peserta juga mendapatkan gambaran real ataupun tips mudah dalam menyusun soal dengan kriteria HOTS.

3. Pemberian tugas diakhir kegiatan pelatihan berupa penyusunan soal kategori HOTS yang terdiri dari tiga soal pilihan ganda dan dua soal uraian bagi setiap peserta beserta kelengkapannya.

Untuk mengetahui tingkat pemahaman peserta pelatihan terhadap materi yang telah disampaikan terutama pemaham peserta terkait HOTS, peserta wajib menjawab sejumlah butir pertanyaan berhubungan dengan HOTS dalam bentuk pretest dan postest. Aktivitas pretest dilakukan sebelum pelatihan dimulai sedangkan postest dimulai setelah pelatihan selesai dengan butir pertanyaan yang sama. Hasil aktivitas ini menunjukkan bahwa adanya peningkatan pemahaman peserta terhadap HOTS setelah dilaksanakan kegiatan pelatihan yaitu sebesar 17.5\%. Adapun deskripsi dalam bentuk diagram hasil pretest dan postest disajikan dalam Gambar 2. 


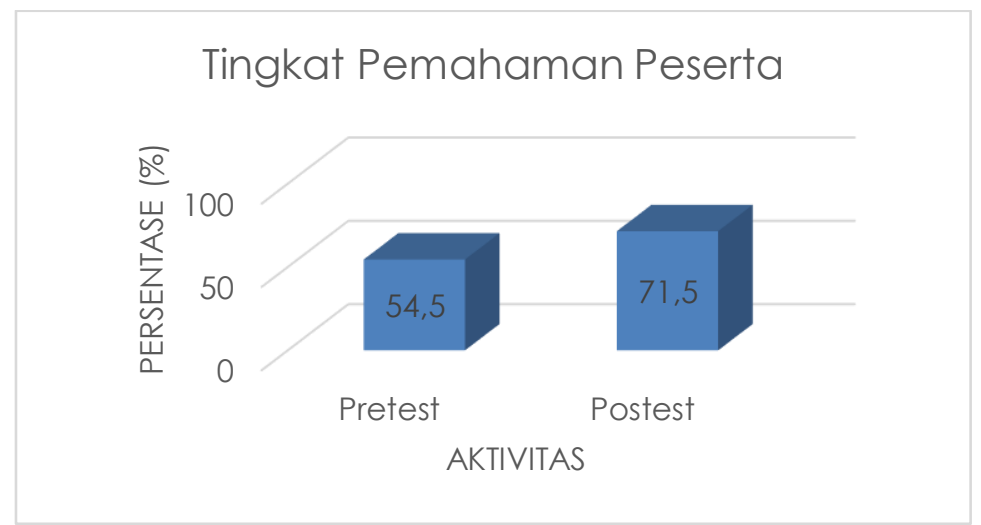

Gambar 2. Persentase Pemahaman Peserta Terkait HOTS

\section{Telaah Soal}

Dari 30 peserta yang mengikuti pelatihan, sebanyak 24 orang telah mengirimkan soal ke tim pelaksana pengabdian masyarakat. Selanjutnya soal-soal tersebut ditelaah oleh tim penelaah yang terdiri dari dosen dan mahasiswa. Instrumen telaah dan kriteria soal yang diterima telah disusun oleh tim pelaksana pengabdian masyarakat. Salah satu kriteria yang ditelaah adalah orisinalitas (keaslian) soal yang dibuat. Pada telaah awal, dari 30 peserta hanya 24 orang yang telah mengumpulkan soal untuk di telaah, dari 24 peserta yang mengirim soal hanya 3 orang yang jumlahnya kurang dari lima (2 orang mengirim 4 soal, sedangkan seorang lagi baru mengirim 2 soal). Terdapat beberapa kondisi terkait soal yang dibuat peserta, yaitu 1) tidak memenuhi aspek orisinalitas; 2) soal yang disusun belum memenuhi kriteria HOTS; dan 3) kurang memenuhi kaidah penyusunan soal yang baik. Bagi soal dengan kriteria di atas, tim pelaksana segera mengirim umpan balik kepada peserta untuk mengganti/memperbaiki soal yang dibuat. Sedangkan hasil telaah akhir disampaikan secara daring pada pertemuan rutin MGMP Matematika SMA wilayah Tuban secara daring pada 27 November 2020 sekaligus sebagai penutupan dari serangkaian kegiatan pengabdian kepada masyarakat.

\section{Evaluasi Pelatihan}

Evaluasi pelaksanaan pelatihan dilakukan dalam bentuk penilaian kegiatan pelatihan oleh peserta melalui angket yang terdiri dari pertanyaan pilihan ganda dan pertanyaan terbuka. Pengisian angket dilakukan pada akhir kegiatan pelatihan. Hasil evaluasi melalui angket yang telah diisi oleh pesertaterhadap sejumlah pertanyaan yang diajukan adalah sebagai berikut: 
1. Peserta menyatakan bahwa materi pelatihan merupakan hal yang baru.

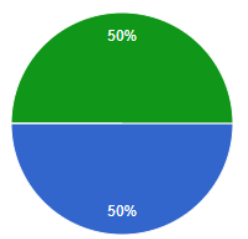

merupakan hal yang baru

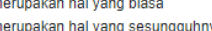
lam

2. Peserta menyatakan bahwa materi pelatihan sangat membantu untuk melaksanakan tugas sebagai Guru.

3. Peserta menyatakan bahwa pelatihan ini sangat bermanfaat dalam pengembangan profesi

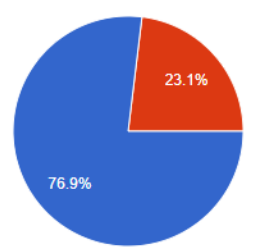

- ya, sangat membant - cukup membantu kurang membant

\section{Guru}

4. Peserta menyatakan pelaksanaan pelatihan cukup efektif.

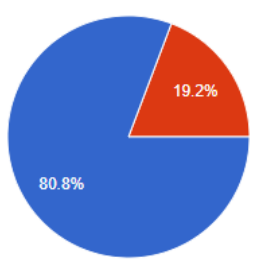

ya, sangat bermanfa - cukup bermanfaat kurang bermanfaat - tidak bermanfaat

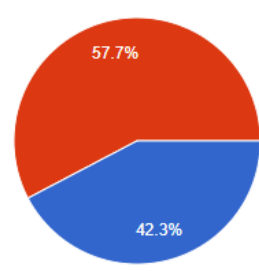

5. Peserta menyatakan kemampuan narasumber dalam menyajikan materi sangat baik.

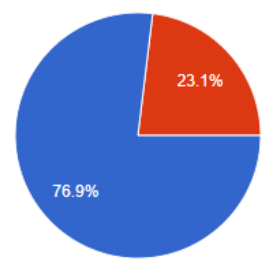

6. Peserta menyatakan kemampuan narasumber dalam penguasaan kelas sangat baik.

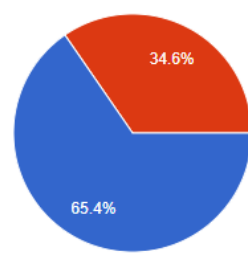

Sementara dari pertanyaan terbuka dapat ditarik kesimpulan bahwa : 
1. Sikap/ pelayanan tim pelaksana pengabdian masyarakat sejak proses registrasi hingga pelaksanaan dinilai baik, memuaskan, menyenangkan, ramah.

2. Untuk pelatihan berikutnya, topik yang peserta butuhkan diantaranya media pembelajaran, pendalaman soal HOTS, penulisan karya tulis.

\section{Evaluasi Penyusunan Soal}

Kegiatan evaluasi penyusunan soal ini dilaksanakan pada tanggal 24 November 2020 secara daring. Evaluasi dilakukan dengan mengkaji bersama soalsoal yang telah disusun oleh peserta. Hasil telaah disampaikan oleh tim pelaksana disertai dengan diskusi dan tanya-jawab dengan peserta. Dari 30 peserta yang mengikuti pelatihan, sebanyak 24 peserta telah mengirimkan soal ke tim pelaksana pengabdian kepada masyarakat. Selanjutnya soal-soal tersebut ditelaah oleh tim penelaah (reviewer). Proses telaah ini terdiri dari tiga tahap yaitu tahap orisinalitas, tahap telaah 1 dan tahap telaah 2. Dari 24 peserta yang telah mengirimkan soal, terdapat 22 peserta yang lanjut ke tahap telaah selanjutnya sedangkan lainnya melakukan perbaikan soal. Hasil telaah secara umum terhadap soal yang telah ditelaah dapat dikatakan bahwa $80,8 \%$ soal yang telah dibuat oleh peserta telah memenuhi aspek orisinalitas dan 31,0\% soal yang disusun telah memenuhi kriteria HOTS. Soal-soal yang telah ditelaah tersebut dikumpulkan dalam sebuah buku elektronik (e-book) dengan ketentuan bahwa soal tersebut memenuhi kriteria orisinalitas, kelogisan serta perbaikan minor. Kumpulan soal tersebut diharapkan dapat menjadi referensi bagi guru SMA Matematika khususnya di wilayah Tuban dalam penyusunan soal berikutnya.

\section{Luaran Kegiatan}

Luaran kegiatan pengabdian kepada masyarakat ini adalah publikasi artikel ilmiah pada jurnal ber-ISSN, publikasi artikel pada media massa elektronik, video kegiatan serta adanya peningkatan keberdayaan mitra. Di samping itu terdapat luaran tambahan berupa kumpulan soal yang disusun oleh peserta yang dibukukan secara elektronik (e-book).

\section{KESIMPULAN}

Berdasarkan hasil dan pembahasan serta rangkaian kegiatan pengabdian kepada masyarakat yang telah terlaksana dapat disimpulkan bahwa kemampuan peserta 


\section{Indonesian Engagement Journal}

Vol. 2 No. 1 Juni 2021

dalam pemahaman materi matematika cukup baik, terutama kompetensi mereka terkait substansi/materi pembelajaran. Kompetensi peserta dalam menyusun soal cukup baik, dari sisi teknis penyusunan maupun kelogisan soal yang dibuat. Namun perlu adanya dorongan, motivasi dan keinginan yang tinggi dari peserta untuk dapat menyusun soal berkategori HOTS lebih baik lagi. Kegiatan pelatihan dinilai cukup efektif dalam meningkatkan kompetensi peserta. Keberlanjutan dari program pengabdian masyarakat ini dapat berupa pembuatan media pembelajaran yang dibutuhkan oleh peserta dalam pembelajaran secara daring.

\section{DAFTAR PUSTAKA}

Profil Kabupaten Tuban (2020), https://tubankab.go.id/page/profil-tuban, akses 23 Maret

Pusat Penilaian Pendidikan Kementerian Pendidikan dan Kebudayaan (2020), https://hasilun.puspendik.kemdikbud.go.id/\#2018!smp!capaian_nasional!99\& 99\&999!T\&T\&T\&T\&1\&!1!\&, akses 23 Maret 2020.

Riyana, A, "Taksonomi Bloom (Ranah Kognitif, Afektif, dan Psikomotor) (2020), https://kangmaszakki.wordpress.com/2017/09/23/taksonomi-bloomranahkognitif-afektif-dan-psikomotor/, akses 24 Maret 2020.

Rukmini, E, (2020) "Deskripsi Singkat Revisi Taksonomi Bloom," https://journal.uny.ac.id/index.php/mip/article/viewFile/7132/6155, akses 24 Maret 2020.

Wikihow (2020), "Cara Meningkatkan Ketrampilan Analitis," https://id.wikihow.com/Meningkatkan-Keterampilan-Analitis, akses (23 Maret 2020. 